\title{
IMPRESI PERMAINAN BOLAKU-TEMANKU TERHADAP PEMBENTUKAN KARAKTER KERJASAMA SISWA SEKOLAH DASAR
}

\author{
Andreas J. F. Lumba ${ }^{1)}$, Jusuf Blegur ${ }^{2)^{*}}$ \\ ${ }^{1}$ Fakultas Keguruan dan Ilmu Pendidikan, Universitas Kristen Artha Wacana, Kupang \\ email: andreaslumba@ukaw.ac.id \\ ${ }^{2}$ Fakultas Keguruan dan Ilmu Pendidikan, Universitas Kristen Artha Wacana, Kupang \\ email: jusufblegur@ukaw.ac.id
}

\begin{abstract}
Playing activities and games in learning have helped students develop themselves holistically. They look highly expressive to cultivate their thoughts, behavior, and feelings during the play. The purpose of this research was to examine the impression of the game My ball-My friend toward the cooperation character of students. This research used One Group Pre-test Post-test Design involving 35 elementary school students with one-semester treatment. The data was collected using a questionnaire and was analyzed descriptively and t-test to categorize as well as to test the impression of the game My ball-My friend. The results prove that My ball-My friend game can impress students' character cooperation through warming-up and cooling down activities at the same time with games, students are also taught that to be able to cooperate optimally, they must accept the various disparities of group members. Thus, My ball-My friend game activity can be a reference for teachers in developing students' character cooperation in learning activities.
\end{abstract}

Keyword:, My ball-My friend, physical education, warming-up-cooling down

\begin{abstract}
Abstrak: Aktivitas bermain dan permainan dalam pembelajaran telah membantu siswa mengembangkan diri secara holistik. Mereka terlihat begitu ekspresif untuk menggerakan pikiran, perilaku, dan perasaannya selama bermain. Tujuan penelitian ini ialah untuk menguji impresi permainan Bolaku-Temanku terhadap karakter kerjasama siswa. Penelitiannya menggunakan One Group Pre-test-Posttest Design yang melibatkan 35 siswa sekolah dasar dengan perlakuan selama satu semester. Data kerjasama siswa dikumpulkan menggunakan kuesioner dan dianalisis secara deskriptif dan t-test guna melakukan kategorisasi serta menguji impresi dari permainan Bolaku-Temanku. Hasil membuktikkan bahwa permainan Bolaku-Temanku dapat mengimpresi karakter kerjasama siswa melalui aktivitas warming-up dan cooling down sekaligus dengan permainan, siswa juga diajarkan bahwa untuk dapat bekerjasama secara maksimal, maka mereka harus saling menerima berbagai disparitas dari anggota kelompok. Dengan demikian, aktivitas permainan Bolaku-Temanku dapat menjadi satu referensi bagi guru dalam mengembangkan karakter kerjasama siswa dalam kegiatan pembelajaran.
\end{abstract}

Kata kunci: Bolaku-Temanku, pendidikan jasmani, warming-up-cooling down

\section{PENDAHULUAN}

Wacana pendidikan karakter akhirakhir ini kian menguat didengungkan dalam dunia pendidikan. Karakter dipandang sebagai salah satu pilar penting dalam pengembangan kualitas diri seorang manusia dalam iklim kerjanya. Untuk itu, Wuryandani, Maftuh, Sapriya, \& Budimansyah (2014:286) merekomendasikan agar penguatan 
pendidikan karakter perlu dilaksanakan sedini mungkin dimulai dari lingkungan keluarga, sekolah, dan meluas ke dalam lingkungan masyarakat.

Salah satunya karakter yang juga diperlukan ialah kerjasama. Kerjasama merupakan upaya seorang siswa untuk memberi dan membuka diri kepada orang lain. Keterbukaan diri ini sekaligus menyiratkan bahwa orang lain juga memiliki kontribusi dalam pencapaian suatu tujuan bersama. Misalnya dalam kegiatan pembelajaran, Lukas membutuhkan Aksamina untuk membantu memberi pemahaman tentang manfaat kesegaran jasmani. Atau Jendry yang meminta Ruth agar mencontohkan teknik melakukan passing bawah yang benar dalam permainan bolavoli.

Kerjasama merupakan salah satu bentuk interaksi sosial (Sari, 2013:310), yang juga merupakan salah satu aspek afektif yang utama dalam sebuah pembentukan karakter individual maupun kesuksesan sebuah kelompok (Adyarta, Hartono, \& Pramono, 2012:57). Saat siswa berada dalam lingkungan kerja, ia tidak hanya membutuhkan keterampilan dan pengetahuan, tetapi ia juga membutuhkan kerjasama (teamwork) untuk menyelesaikan suatu permasalahan (Wulandari, Arifin, \& Irmawati, 2015:9). Untuk itu, melatih kerjasama amatlah penting bagi siswa.

Proses pembelajaran pendidikan jasmani, olahraga, dan kesehatan (Penjasorkes) telah ada di sekolah dasar (SD) yang juga memberi andil dalam pembentukan karakter kerjasama siswa. Namun kadangkala guru mengarahkan siswa kepada pembelajaran yang syarat dengan kepentingan guru tanpa memperhatikan keanekaragaman siswa. Desain pembelajaran yang bersifat informatif, verbalisasi, dan berorientasi pada latihan-latihan "keolahragaan" kerap membuat siswa jenuh untuk belajar.
Padahal ada banyak potensi yang dapat guru latih dan kembangkan dalam kegiatan pembelajarannya, termasuk karakter kerjasama melalui permainan-permainan.

Ketepatan guru dalam memilih pendekatan pembelajaran akan sangat membantu siswa dalam belajar. Sebagai contoh yang dikhawatirkan Suherman (2009:3) dan Hidayanto (Suherman, 2010:132-133), bahwa jika guru menggunakan pendekatan pembelajaran drill, hanya menekankan pada penguasaan motorik, dan bersifat spekulatif semata. Implikasinya pembelajaran kurang menarik, siswa cenderung acuh tak acuh, kurang termotivasi, merasa bosan, dan kurang kreatif, dan tidak menantang.

Penjasorkes juga mengenal pendekatan pembelajaran melalui play dan game. Pendekatan ini tidak sebatas mengajarkan skill siswa, tetapi lebih memberdayakan siswa untuk menggunakan skill atau potensi dirinya melalu berbagai aktivitas bermain dan permainan. Agar pendekatan pembelajaran melalui bermain dan permainan dapat diterapkan di semua lapisan pendidikan formal, maka dilakukan modifikasi permainan dalam Penjasorkes, sehingga modifikasi permainan tersebut dapat membentuk karakter siswa (Basuki, 2011:68).

Siswa SD mudah belajar dengan keadaan-keadaan yang lebih natural. Siswa berjalan, berlari, berlompat, dan berguling, sesuai dengan kehandak dan keinginannya. Dalam suasana yang alamiah, siswa lebih santai dan gembira dalam memahami dan mempraktikkan informasi pembelajaran. Ini akan lebih mudah jika guru yang kompeten dapat melakukan pendekatan, metode, dan strategi belajar yang kompatibel dengan kebutuhan belajar siswa (Blegur, Wasak, Manu, 2017:118), misalnya dengan metode bermain dan permainan. Suparman (2010:169) mengutarakan bahwa ketika bermain, siswa merasa gembira, tidak ada 
beban apapun dalam pikiran. Suasana hati senantiasa ceria. Dalam keceriaan inilah guru dapat dengan mudah menyelipkan ajaran-ajarannya.

Dunia anak-anak ialah bermain, mereka dapat belajar selama bermain. Anak belajar berbagai macam informasi saat ia bermain, dari menggerakkan anggota tubuhnya hingga mengenali berbagai benda di lingkungan sekitarnya (Husdarta, 2011:12). Bermain membantu siswa belajar mengenal lingkungan di sekitarnya, belajar dalam menguasai beberapa keterampilan hidup seperti keterampilan berbahasa, bersosialisasi, dan lainnya (Juniarti \& Gustiana, 2019:39). Dengan demikian, saat bermain siswa mendapatkan pengetahuan dan pengalaman yang menyiapkan diri dalam kehidupan selanjutnya (Khasanah, Prasetyo, \& Rakhmawati, 2011:94).

Bermain mempunyai peran penting dalam kegiatan pembelajaran. Bermain dapat melengkapi kegiatan sekolah siswa, yang memberi kesempatan kepada siswa untuk memahami, meresapi, dan memberi arti kepada apa yang dipelajarinya dalam setting pendidikan formal (Nur, 2013:90). Selain itu, bermain juga dapat meningkatkan karakter siswa (Basuki, 2011:63; Endriani \& Verawati, 2013:99), misalnya mampu membentuk sikap kerjasama siswa (Adyarta, Hartono, \& Pramono, 2012:57), mengembangkan kontrol diri (Suherman, 2016:194), serta meningkatkan motivasi siswa berkesulitan belajar (Ramadhani, Azwandi, \& Martias, 2013:47).

Bermain dan belajar tidak dapat dipisahkan dalam dunia siswa (Blegur \& Wasak, 2017:252), sebab bermain merupakan pengalaman belajar yang amat menyenangkan dalam kehidupan siswa (Fanany, 2013:51) sehingga memacu siswa menjadi aktif dan partisipatif dalam proses pembelajaran. Bermain terbukti dapat meningkatkan kemampuan membaca siswa
(Aulina, 2012:131), serta dengan bermain, membuat siswa melewati kegiatan belajar dengan lebih efektif, efisien, dan menyenangkan (Prabowo, 2015:272). Penelitian ini bertujuan untuk menguji impresi permainan Bolaku-Temanku terhadap karakter kerjasama siswa dalam kegiatan warming-up dan cooling down pada pembelajaran Penjasorkes.

\section{METODE PENELITIAN}

Desain

Penelitian ini menggunakan One Group Pre-test-Post-test Design, di mana tidak menggunakan kelompok kontrol dan subyek tidak ditempatkan secara acak. Akan tetapi dilakukan pre-test dan post-test untuk mendapatkan hasil akibat perlakuan (Maksum, 2012:97). Sebelum memulai perlakuan, kami mengambil data karakter kerjasama siswa menggunakan kuesioner. Perlakuan permainan Bolaku-Temanku dilaksanakan selama satu semester pembelajaran dalam kegiatan warming-up dan atau cooling-down. Kami kembali mengambil data kerjasama siswa menggunakan kuesioner yang sama untuk melihat perbedaan impresi dari perlakuan permainan Bolaku-Temanku.

\section{Prosedur}

Subyek dibentuk dalam 7 kelompok bermain, dengan tiap anggota kelompok 5 orang yang ditentukan secara random. Mereka berjalan menuju garis finish sesuai lintasan yang telah disiapkan (9 meter) guru di area lapangan sekolah. Setiap kelompok menempatkan bola plastik diantara dahi dan kepala belakang lalu berupaya menjaga bola tersebut agar tidak terjatuh selama berjalan hingga sampai ke garis finish. Apabila bola tersebut terjatuh, maka mereka harus segera mengambil bola dan melanjutkan permainan sebagaimana mestinya. Setiap anggota harus bekerjasama dengan baik, agar mereka dapat memasuki 
garis finish dengan menjatuhkan bola di tengah-tengah permainan.

Peneliti dan guru telah menetapkan waktu 15 detik untuk lintasan 9 meter. Setiap kelompok harus bertanggung jawab dengan bolanya, menjaga irama langkah, saling interaksi dan komunikasi, serta terampil agar mereka dapat masuk garis finish dengan waktu 15 detik tanpa menjatuhkan bola. Apabila mereka mampu melakukannya, maka diasosiaikan subyek memiliki kerjasama yang baik.

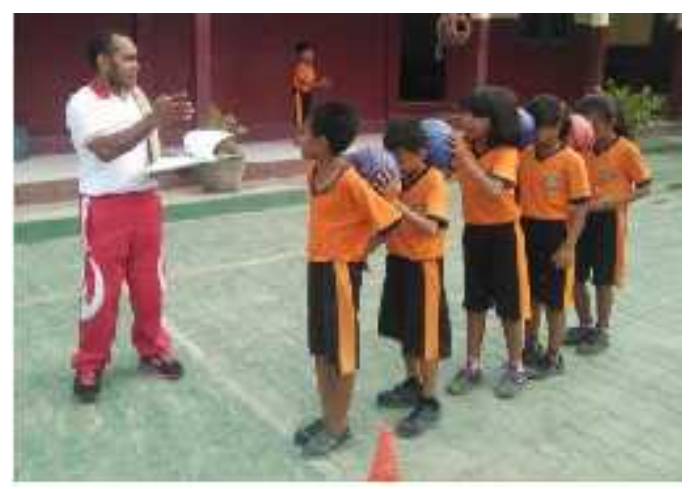

Gambar 1. Arahan guru sebelum melaksanakan permainan Bolaku-Temanku

\section{Lokasi dan Sampel}

Lokasi penelitian adalah Sekolah Dasar Negeri Balfai, Kecamatan Kupang Tengah, Kabupaten Kupang, Propinsi Nusa Tenggara Timur. Sampel penelitian ialah siswa-siswi kelas 4 yang berjumlah 35 orang, terdiri dari 15 pria dan 20 wanita (M $=9,5143, \mathrm{SD}=0,78108$ ).

\section{Instrumen}

Merefensi pada lima indikator kerjasama dari Johnson, Johnson, \& Holubec (2012:196), peneliti merumuskan sub-indikator dalam kuesioner penelitian, yaitu: 1) Adanya saling ketergantungan yang positif diantara individu-individu dalam kelompok tersebut untuk mencapai tujuan (1-2), 2) Adanya interaksi tatap muka yang dapat meningkatkan sukses satu sama lain diantara anggota kelompok (3-4), 3) Adanya tanggungjawab personal individu (5-6), 4) Adanya keterampilan komunikasi interpersonal dan kelompok kecil (7-8), dan 5) Adanya keterampilan bekerja dalam kelompok (9-10).

Pengembangan kuesioner ini dikontekstualisasikan dengan aktivitas bermain dan berlomba sehingga mempermudah siswa dalam menanggapi. Nilai reliabilitas kuesioner ini sebesar 0,755 $(\mathrm{N}=15)$.

Tabel 1. Kuesioner kerjasama siswa

\begin{tabular}{|c|c|c|}
\hline No & Pernyataan & Tanggapan \\
\hline & $\begin{array}{l}\text { Saya membutuhkan } \\
\text { dukungan teman agar bisa } \\
\text { bermain dan berlomba dalam } \\
\text { kelompok }\end{array}$ & $\begin{array}{lllll}5 & 4 & 3 & 2 & 1\end{array}$ \\
\hline & $\begin{array}{l}\text { Saya dibutuhkan kelompok } \\
\text { saat bermain dan berlomba } \\
\text { agar mencapai finish }\end{array}$ & $\begin{array}{lllll}5 & 4 & 3 & 2 & 1\end{array}$ \\
\hline & $\begin{array}{l}\text { Saya dan teman lain perlu } \\
\text { mendiskusikan dan } \\
\text { menceritakan cara kami } \\
\text { bermain dan berlomba agar } \\
\text { lebih bagus }\end{array}$ & $\begin{array}{lllll}5 & 4 & 3 & 2 & 1\end{array}$ \\
\hline & $\begin{array}{l}\text { Saya memberi masukan atau } \\
\text { solusi untuk memperbaiki } \\
\text { kualitas bermain dan } \\
\text { berlomba kelompok kami }\end{array}$ & $\begin{array}{lllll}5 & 4 & 3 & 2 & 1\end{array}$ \\
\hline & $\begin{array}{l}\text { Saya memperhatikan usaha } \\
\text { teman lain agar seimbang } \\
\text { dalam bermain dan } \\
\text { berlomba }\end{array}$ & $\begin{array}{lllll}5 & 4 & 3 & 2 & 1\end{array}$ \\
\hline & $\begin{array}{l}\text { Saya menjaga agar tidak } \\
\text { gagal saat bermain dan } \\
\text { berlomba }\end{array}$ & $\begin{array}{lllll}5 & 4 & 3 & 2 & 1\end{array}$ \\
\hline & $\begin{array}{l}\text { Saya memberi semangat agar } \\
\text { kelompok kami dapat } \\
\text { bermain dan berlomba } \\
\text { dengan baik }\end{array}$ & $\begin{array}{lllll}5 & 4 & 3 & 2 & 1\end{array}$ \\
\hline & $\begin{array}{l}\text { Saya mau mendengarkan } \\
\text { pendapat teman dalam } \\
\text { kelompok untuk kemajuan } \\
\text { kelompok kami saat bermain } \\
\text { dan berlomba }\end{array}$ & $\begin{array}{lllll}5 & 4 & 3 & 2 & 1\end{array}$ \\
\hline & $\begin{array}{l}\text { Saya senang bermain dan } \\
\text { berlomba bersama orang lain } \\
\text { dalam kelompok }\end{array}$ & $\begin{array}{lllll}5 & 4 & 3 & 2 & 1\end{array}$ \\
\hline & $\begin{array}{l}\text { Saya memiliki kemampuan } \\
\text { untuk bermain dan berlomba }\end{array}$ & $\begin{array}{lllll}5 & 4 & 3 & 2 & 1\end{array}$ \\
\hline
\end{tabular}

\section{Analisis Data}

Data penelitian dianalisis secara deskriptif kuantitatif dan t-test. Analisis deskriptif kuantitatif untuk memotret 
karakter kerjasama siswa, sedangkan analisis t-test digunakan untuk menguji perbedaan permainan Bolaku-Temanku terhadap karakter kerjsama siswa sebelum dan setelah melewati perlakuan selama satu semester. Apabila nilai $t_{\text {hitung }}$ lebih besar dari $t_{\text {tabel, }}$, atau nilai Sig lebih kecil dari 0,05, maka terdapat perbedaan kerjasama siswa yang signifikan antara hasil pre-test dan hasil post-test.

Tabel 2. Kategorisasi karakter kerjasama

\begin{tabular}{cc}
\hline Nilai & Kategori \\
\hline $43-50$ & Sangat baik \\
\hline $35-42$ & Baik \\
\hline $27-34$ & Cukup baik \\
\hline $19-26$ & Kurang baik \\
\hline $10-18$ & Tidak baik \\
\hline
\end{tabular}

\section{HASIL DAN PEMBAHASAN \\ Deskripsi Nilai Pre-Test}

Hasil penelitian diawali dengan mengukur karakter kerjasama siswa sebelum diberikan perlakukan permainan Bolaku-Temanku. Pengukuran dan penilaian karakter kerjasama berkaitan dengan proses kategorisasi karakter kerjasama siswa, yakni dari yang berkategori "tidak baik" sampai dengan "sangat baik". Adapun hasil pengujian deskriptif kuantitatif tentang nilai pre-test karakter kerjasama sama siswa disajikan pada histogram berikut.

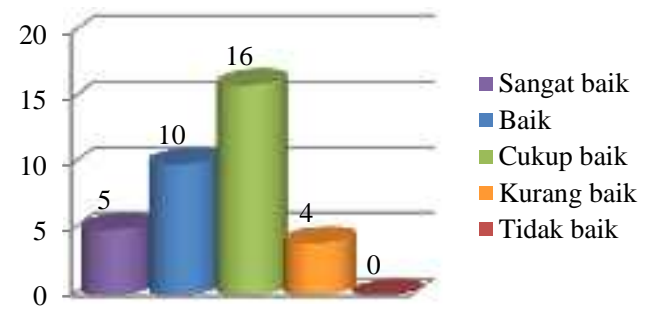

Gambar 2. Nilai pre-test karakter kerjasama siswa

Hasil pengujian terlihat bahwa data karakter kerjasama siswa sebelum melakukan permainan Bolaku-Temanku tegolong "cukup" $(45,71 \%)$ dengan mean sebesar 34,08 dan simpangan baku sebesar
6,39 . Adapun nilai minimumnya sebesar 22 $(2,85 \%)$ dan nilai maksimum sebesar 47 $(5,71 \%)$. Kategori karakter kerjasama siswa tergolong "cukup", ini menunjukkan bahwa kondisi perkembangan anak SD bersifat "netral", karena pada dasarnya setiap orang ingin terlibat dalam sebuah kelompok untuk menjalankan aktivitas saling membantu antar satu sama lain.

Salah satu kebutuhan dasar anak SD ialah ingin diperhatikan. Untuk itu mereka juga memiliki insiatif dalam menjaga dan menyalurkan karakter kerjasama dalam kelompok-kelompok bermain dan belajar. Lihat saja, saat siswa terlibat dalam kelompok belajar dan bermain, mereka begitu ekspresif untuk saling mengingatkan sampai bahkan saling "memarahi" satu sama lain. Tindakan demikian tidak lantas menyiratkan bahwa mereka saling membenci, sebab itu terjadi tanpa adanya "hidden" motivasi, melainkan lebih kepada suasana yang natural.

Ekspresi "kemarahan" itu sebenarnya perwujudan dari semangat anak SD untuk mengingatkan rekan lainnya dalam kelompok untuk tetap menjaga irama sehingga bisa bergerak bersama-sama untuk mencapai tujuan. Tentu amat berbeda apabila ekspresi kemarahan dilakukan oleh siswa yang sudah "mengerti", sebab itu akan lebih bersifat justifikatif untuk mencari pembenaran dengan memanfaatkan kelalaian siswa lainnya. Dengan demikian, data pre-test menjelaskan bahwa siswa masih mampu menjaga netralitas untuk menjaga karakter kerjasamanya dalam kelompok belajar, bermain, dan sebagainya.

\section{Deskripsi Nilai Post-Test}

Setelah melewati serangkaian perlaku permainan Bolaku-Temanku dalam bentuk aktivitas warming-up dan cooling down, siswa kembali diukur perkembangan 
karakter kerjasamanya. Ini sebagai bentuk pengujian sekaligus pembuktian dari impresi permainan Bolaku-Temanku terhadap karakter kerjasama siswa SD dalam pembelajaran Penjasorkes. Pengujian deskriptif ini juga masih bertalian dengan proses kategorisasi karakter kerjasama siswa sebagaimana yang dilakukan pada pre-test.

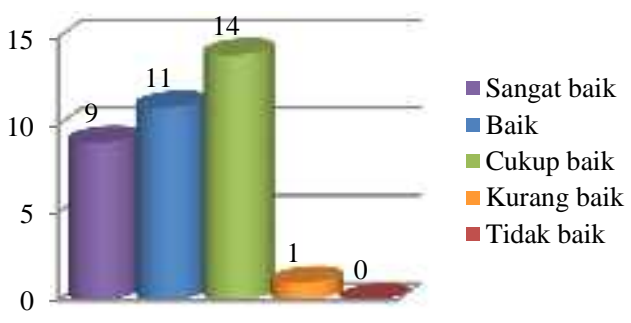

Gambar 3. Nilai post-test karakter kerjasama siswa

Gambar 3 menunjukkan data pengujian karakter kerjasama siswa setelah melewati perlakuan permainan BolakuTemanku tergolong "baik" (85,7\%). Sedangkan mean sebesar 36,45, simpangan baku sebesar 6,19, nilai minimum adalah 25, dan nilai maksimum adalah 49. Data ini juga menunjukkan adanya perbedaan peningkatkan pada kategori "baik" sebesar $2,85 \%$ dan kategori "sangat baik" sebesar $11,42 \%$. Sedangkan kategori karakter kerjasama siswa yang mengalami penurunan ialah "cukup" sebesar 5,71\% dan kategori "kurang baik" sebesar 8,57.

\section{Paired Sampel T-Test}

Sebelum melakukan pengujian hipotesis penelitian, terlebih dahulu dilakukan pengujian normalitas data seperti pada tabel 3 .

Tabel 3. Uji normalitas data

\begin{tabular}{ccccc}
\hline & \multicolumn{2}{c}{$\begin{array}{l}\text { Kolmogorov- } \\
\text { Smirnov }\end{array}$} & \multicolumn{2}{c}{ Shapiro-Wilk } \\
\hline & Statistic & Sig. & Statistic & Sig. \\
\hline Pre-test & 0,085 & $0,200^{*}$ & 0,980 & 0,752
\end{tabular}

\begin{tabular}{lllll}
\hline Post-test & 0,136 & 0,101 & 0,961 & 0,237 \\
\hline *. This is a lower bound of the true significance
\end{tabular}

a. Lilliefors significance correction

Hasil uji normalitas data karakter kerjasama pada pre-test (KolmogorovSmirnov $=0,200 ;$ Shapiro-Wilk $=0,752$ ) maupun post-test (Kolmogorov-Smirnov = 0,101; Shapiro-Wilk $=0,237$ ) sama-sama menunjukkan bahwa sebaran datanya normal kerena lebih besar dari nilai signifikansi $(0,05)$, sehingga memenuhi prasyarat untuk dilakukan uji hipotesis.

Pengujian hipotesis menggunakan uji paired samples t-test karena penelitin ini menggunakan subjek yang sama namun mendapatkan perlakuan berbeda. Hasil pengujian hipotesis terlihat pada tabel 4 .

Tabel 4. Hasil paired samples t-test

\begin{tabular}{cccc}
\hline & $\mathrm{t}$ & $\mathrm{df}$ & $\begin{array}{c}\text { Sig. (2- } \\
\text { tailed) }\end{array}$ \\
\hline Pre-test-post-test & $-4,660$ & 34 & 0,000 \\
\hline
\end{tabular}

Hasil pengujian hipotesis penelitian yang tersaji pada tabel 4 membuktikan bahwa terdapat impresi yang signifikan antara permainan Bolaku-Temanku terhadap karakter kerjasama siswa dalam pembelajaran Penjasorkes (0,000 0,05). Dengan demikian, aktivitas bermain dan permainan perlu diterapkan dan dikembangkan guru dalam aktivitas warming-up dan atau cooling down sebagai bentuk dari proses internalisasi penanaman sekaligus pembiasaan karakter kerjasama siswa.

\section{Warming-Up dan Cooling Down: Tidak Sebatas Manfaat Fisik}

Warming-up dan cooling down dalam pembelajaran Penjasorkes kerap diasosisikan kepada kebermanfaatan fisik. Anggapan ini dikarenakan kedua aktivitas tersebut cenderung dipakai sebagai "pelengkap" dalam pembelajaran. Padahal keduanya sama-sama memiliki posisi strategis dalam pencapaian tujuan pembelajaran. Hasan, Winarno, \& Tomi 
(2015:191) menjelaskan bahwa permainan dalam pembelajaran Penjasorkes digunakan hanya untuk menumbuhkan aspek kebugaran jasmani dan rohani. Pandangan ini amat terbatas, karena permainan tidak sesederhana itu manfaatnya. Inisiasi internalisasi aktivitas permainan (misalnya Bolaku-Temanku) dalam kegiatan warming-up dan cooling down tentu harus bermanfaat ganda. Tidak sekedar untuk fisik semata, namun siswa juga harus dilatih untuk kecakapan lainnya, satu diantaranya adalah karakter kerjasama.

Bermain memberi kesempatan kepada siswa untuk bereksplorasi, melatih kesejahteraan kognitif, melatih kemampuan menemukan masalah, mengekspresikan perasaan, melatih kemampuan sosial dan emosional, berkreasi dengan maksimal, serta belajar secara menyenangkan (Ginsburg, 2007:182; Syaukani \& Subekti, 2018:97), selain itu bermain termasuk media pembelajaran bahasa (Tomlinson \& Masuhara, 2009:1) serta mampu meningkatkan karakter kerjasama siswa (Tiyanti \& Saparahayuningsih, 2017:28). Nilai-nilai kerjasama dan atau lainnya dapat disiasati oleh guru dalam merancang aktivitas bermain dan permainannya. Hal ini mudah tercermin dari bagaimana guru membentuk permainan dari regulasiregulasinya. Rumusan regulasi tersebut dapat guru arahkan kepada karakter apa yang mau dilatihkan kepada siswa, misalnya saja permainan Bolaku-Temanku untuk membentuk karakter kerjasama siswa. Ini dapat ditempatkan pada kegiatan warming-up maupun cooling-down, tapi juga dapat dikembangkan pada inti pembelajaran dengan memperhatikan karakterisasi materinya.

Warming-up dan cooling down yang konvensional berfokus pada dominasi fisik semata. Mengapa demikian? Karena siswa hanya akan dianjurkan melakukan gerakangerakan statis (non-lokomotor) ataupun hanya sekedar berlari dalam menit tertentu (lokomotor). Lantas dengan aktivitas demikian, hampir muatan afeksi miskin ditanamkan kepada siswa, apalagi dalam hal berpikir, lebih diabaikan. Padahal tujuan pembelajaran Penjasorkes ialah mencapai tujuan pendidikan menggunakan media jasmani. Sehingga segala muatan hasil belajar (kognitif dan afektif) harus mampu diakomodasi sesuai proporsinya masingmasing.

Proses belajar bukan hanya ada pada aktivitas inti pembelajaran (meskipun proporsi waktunya tinggi), namun juga pada aktivitas warming-up dan cooling down. Untuk itu sajikanlah berbagai bentuk aktivitas bermain dan permainan dalam tiap tahapan belajar agar mengembangkan rangkaian aktivitas yang bermanfaat simultan pada pencapaian potensi diri dan hasil belajar siswa. Lewat warming-up dan cooling down yang berbasis pada aktivitas bermain dan permainan, guru dapat memaksimalkan pencapaian tujuan pendidikan, karena sejumlah sektor hasil belajar lebih maksimal dieksplorasi, baik secara parsial maupun simultan. Untuk itu, Mckeen, Webb, \& Pearson (2007:251) menyarankan agar guru Penjsorkes perlu mengajar permainan untuk memastikan bahwa siswa terlibat dalam pengalaman belajar yang menyenangkan dan menantang dengan berbagai kemampuan dan tingkat minat terhadap permainan.

\section{Permainan Bolaku-Temanku sebagai Sarana Pembentukan Karakter Kerjasama}

Pembentukan karakter kerjasama bisa dilakukan dengan berbagai macam cara, seperti menggunakan metode edutaiment (Pratiwi, Ardianti, \& Kanzunuddin, 2018:177), maupun penerapan soccer like games (Palupi \& Darmawan, 2017:510). Selain cara di atas, pembentukan karakter kerjasama juga 
mampu terbentuk melalui berbagai permainan, termasuk permainan BolakuTemanku. Aktivitas siswa SD bertalian erat dengan bermain dan permainan, sehingga dengan menginternalisasi kebutuhan bermain dan permainan, siswa kian termotivasi dan ekspresif untuk berpartisipasi. Dengan bermain dan permainan, guru dapat menyelipkan seperangkat pengatahuan, keterampilan, dan perilaku sebagai bagian dari pencapaian tujuan belajar tanpa harus memonopoli "dunia" mereka.

Kesulitan guru saat melaksanakan pembelajaran dikarenakan guru cenderung "merampas" kebutuhan belajar siswa, misalnya mengajar dengan metode yang kaku dan monoton serta tidak akseptabel dengan perkembangan piskologi siswa. Padahal siswa belajar bukan dengan preferensi "kecabangan olahraga" yang sama, sehingga strategi yang guru tawarkan harus benar-benar mempertimbangkan peran serta siswa secara holistik. Salah satu media belajar yang mampu menampung seluruh preferensi siswa ialah aktivitas bermain dan permainan. Sehingga guru tinggal menyiasatinya dengan kebutuhan materi dan tujuan pembelajaran agar siswa senang dalam belajar (Fadilah \& Wibowo, 2018:62) serta meningkatkan partisipasi siswa (Fikri \& Mudjihartono, 2016:58). Dengan demikian, guru harus apik memanajelisir kegiatan bermain dan permainan dalam mengafirmasi perkembangan sifat imajinasi siswa selama kegiatan pembelajaran (Blegur \& Wasak, 2017:22).

Lantas bagaimana proses pembentukan kerjasama dalam permainan Bolaku-Temanku? Dalam permainan ini, pembentukan karakter kerjasama ada pada sikap kesungguhan dan keseriusan tiap anggota kelompok untuk mencapai garis finish dengan tidak melakukan pengabaian terhadap tugas dan tanggung jawabnya (manjaga bola agar tidak terjatuh). Selain itu, tiap anggota harus mampu menerima dan terbuka terhadap kelebihan dan keterbatasan kemampuan teman sekelompoknya. Misalnya saja ukuran tinggi badan yang tidak sepadan, kecepatan jalan/lari yang tidak seirama, reaksi emosional yang fluktuatif, maupun jenis kelamin maupun ras yang berbeda.

Walau mereka dihadapkan dengan berbagai disparitas, mereka tetap memiliki visi yang sama, yakni menyelesaikan permainan dengan penuh tanggung jawab (menjaga bola agar tidak terjatuh). Tiap anggota kelompok memiliki cara yang berbeda untuk mempertahankan kerjasama kelompoknya. Beberapa diantaranya, menjaga keseimbangan tubuh dengan mengangkat kedua tangannya saat berjalan dan atau berlari, ada yang mengangkat collarbone kiri lebih tinggi dari collarbone kanannya agar memastikan bola ada dalam posisi yang aman, ada yang memperlambat gerakannya akan teman di belakangnya mampu mengontrol bolanya, dan lain sebagainya (lihat gambar 4).

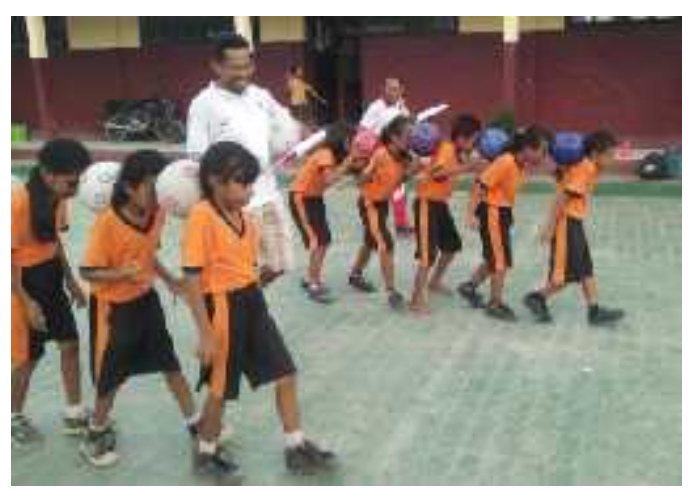

Gambar 4. Ekspresi kerjasama siswa saat mempertahankan bola

Siswa lebih solid dalam bekerjasama karena adanya satu tujuan bersama (sampai finish). Tujuan tersebut yang melatih mereka untuk mampu berperan aktif, mampu menyesuaikan gerakan, serta mampu mengontrol emosi sektoralnya. Ada siswa yang tinggi secara fisik, namun ia harus menunduk agar menyesuaikan fisikya 
dengan teman yang ada di depannya yang kebetulan lebih pendek darinya. Jadi ringkasnya karakter kerjasama siswa lebih optimal dibentuk dalam aktivitas bermain dan permainan yang berkelompok, ada tujuan yang dicapai, serta ada regulasi permainan yang diatur untuk melatih karakter kerjasama.

\section{Karakter Kerjasama: Warisan Bangsa Pluralis yang Wajib Dipertahankan}

Bangsa Indonesia ialah bangsa yang besar dengan keanekaragaman suku, agama, ras, antar golongan. Ini bukan dijadikan sebagai sarana memecah-belah, melainkan media untuk saling memperlengkapi satu satu lain agar tetap saling membutuhkan, selalu harmonis, dan kian tangguh. Perbedaan ini seiring berjalannya tahun kemerdekaan Indonesia, mulai tergerus perlahan-lahan. Hampir diberbagai dimensi kehidupan isu sektoral mulai dipertontonkan, sehingga disparitas ini kian diperalat untuk melegitimasi hegemoni kelompok tertentu, baik di pemerintahan, sosial, politik, tidak terkecuali pendidikan.

Corak demikian adalah virus untuk masa depan anak, virus untuk masa depan keluarga, virus untuk masa depan masyarakat, virus untuk masa depan daerah, maupun virus untuk masa depan Indonesia, dan tentunya virus untuk masa depan peradaban. Untuk itu, di tingkat yang paling dasar dalam dunia pendidikan, guru harus mampu menjadi pelopor sekaligus komando yang terus mempertahankan nilainilai ke-Indonesia-an melalui pembelajaran Penjasorkes, antara lain menghidupkan kembali karakter kerjasama diantara siswa melalui permainan Bolaku-Temanku. Menurut Khoiriah \& Yudiana (2016:29), untuk meningkatkan kerjasama siswa perlu diajarkan keterampilan sosial. Alasannya dengan keterampilan sosial, nilai-nilai dalam kerjasama akan terinternalisasi dalam diri siswa dengan cara pembiasaan, permainan Bolaku-Temanku adalah salah satunya medan pembiasaannya.

Permainan Bolaku-Temanku sebagai wahana yang mampu menjaga karakter kerjasama sebagai warisan bangsa yang pluralis. Permainan ini melatih siswa agar maju dengan tidak menghilangkan rasa kemanusiaan antara sesama. Menjadi maju dengan tidak mengabaikan peran orang lain, menjadi maju dengan tidak menonjolkan kemampuan sektoral, menjadi maju tapi tidak memedulikan orang lain, serta menjadi maju dengan memaksa kehendak sendiri. Permainan BolakuTemanku adalah peristiwa maknawi dari bagaimana siswa menjaga dan merawat bola laksana temannya sendiri, sehingga ia tidak boleh membiarkan bolanya terjatuh, apalagi sengaja menjatuhkannya.

Kerjasama dalam permainan BolakuTemanku sekaligus mengajarkan siswa bahwa kekuatan atau kelebihan siswa perorangan tidak mampu melampaui kekuatan atau kelebihan siswa secara kolektif. Mengapa demikian? Sebab mereka tidak akan berhasil mencapai finish jika mereka tidak membutukan bantuan teman yang ada di depan maupun teman yang ada di belakangnya. Artinya dengan berbagai keterbatasan teman, mereka tetap memberi andil dalam pencapaian tujuan, karena mereka juga turut memberi upaya dengan berpikir, memberikan upaya dalam gerakan, serta memberi upaya dalam semangat. Dengan demikian permainan dapat membantu siswa mengembangkan persahabatan dan rasa memiliki terhadap kelompok sebayanya (Bakirtzoglou \& Ioannou, 2012:26).

\section{SIMPULAN}

Aktivitas berbasis bermain dan permainan telah membantu siswa belajar lebih motivatif, aktif, dan ekspresif, meskipun hanya dipakai pada kegiatan 
warming-up dan cooling down. Mereka seperti sedang belajar dalam bermain, dan inilah yang perlu didorong oleh para guru guna menanamkan kepada siswa bahwa Penjasorkes adalah sebuah pembelajaran yang menyenangkan dan "membebaskan" siswa dari berbagai kejenuhannya dalam belajar. Karena pembelajaran untuk SD ialah menata karakter dan passion mereka pada aktivitas gerak yang ia sukai sekaligus manjaga semangat siswa dalam belajar.

Permainan Bolaku-Temanku adalah salah satu sarana yang terbukti memliki impresi terhadap karakter kerjasama siswa. Walaupun demikian, karakter tersebut terbentuk bukan tanpa strategi guru melalui berbagai rekayasa aktivitas belajar, seperti menempatkan siswa yang ragam karakteristik kelompok, menyiasati regulasi yang berbasis pada perilaku kerjasama, menentukan panjang lintasan dan waktu tempuh, maupun distribusi tugas dari tiap anggota kelompok. Ini sebagai strategi dan upaya guru agar siswa dapat mencapai tujuan yang diharapkan guru yakni menguji impresi permainan Bolaku-Temanku terhadap kerakter kerjasama siswa.

Selain itu, penelitian ini juga membuktikan bahwa siswa dapat bekerjasama bukan karena setiap anggota sepadan dalam banyak hal, melainkan tiap siswa bersedia untuk mau menerima keterbatasan orang lain serta mampu memberikan kemampuan terbaik dalam berbagai disparitas anggota kelompok.

\section{DAFTAR RUJUKAN}

Adyarta, K. D., Hartono, M., \& Pramono, H. (2012). Penerapan Permainan Bola Voli Mini terhadap Pembentukan Aspek Kerjasama Siswa Kelas IV SD. Active: Journal of Physical Education, Sport, and Health, 1(2), 57-60. DOI https://doi.org/10.15294/active.v1i2.4 $\underline{26}$
Aulina, C. N. (2012). Pengaruh Permainan dan Penguasaan Kosakata terhadap Kemampuan Membaca Permulaan Anak Usia 5-6 Tahun. Pedagogia: Jurnal Pendidikan, 1(2), 131-143. DOI:

https://doi.org/10.21070/pedagogia.v $\underline{1 \mathrm{i} 2.36}$

Bakirtzoglou, P., \& Ioannou, P. (2012). The Relationship between Play and Physical Education Lesson. Sport Science, 5(1), 26-42.

Basuki, S. (2011). Pembentukan Karakter melalui Modifikasi Permainan dalam Pembelajaran Pendidikan Jasmani. Jurnal ILARA, 11(1), 63-69.

Blegur, J., \& Wasak, M. R. P. (2017). Permainan Kecil: Teori dan Aplikasi (Cetakan 1). Kupang: Jusuf Aryani Learning.

Blegur, J., Wasak, M. R. P., \& Manu, L. (2017). Penilaian Formatif Peserta Didik atas Kompetensi Pendidik dalam Proses Pembelajaran. Satya Widya, 33(2), 117-127. DOI: https://doi.org/10.24246/j.sw.2017.v3 3.i2.p117-127

Endriani, D., \& Verawati, I. (2013). Upaya Pembentukan Karakter melalui Olahraga Permainan Kecil Pada Siswa SD. Generasi Kampus, 6(2), 99-104. Retrieved from: https://jurnal.unimed.ac.id/2012/inde x.php/gk/article/view/7092

Fadilah, M., \& Wibowo, R. (2018). Kontribusi Keterampilan Gerak Fundamental terhadap Keterampilan Bermain Small-Sided Handball Games. Jurnal Pendidikan Jasmani dan Olahraga, 3(1), 60-68.

Fanany, E. (2013). Guru Sejati Guru Idola (Cetakan 1). Yogyakarta: Araska.

Fikri, I. K., \& Mudjihartono. (2016). Penerapan Model-Model Permainan untuk Meningkatkan Partisipasi Siswa Pada Pembelajaran Aktivitas 
Permainan Rounders. Jurnal Pendidikan Jasmani dan Olahraga, 1(1), 58-67. doi. 10.17509/jpjo.v1i1.3664

Ginsburg, K. R. (2007). The Importance of Play in Promoting Healthy Child Development and Maintaining Strong Parent-Child Bonds. American Academic of Pediatrcis, 119(1) 182-191.

Hasan, S., Winarno, M. E., \& Tomi, A. (2015). Pengembangan Model Permainan Gerak Dasar Lempar untuk Siswa Kelas V SDN Tawangargo 4 Karangploso Malang. Jurnal Pendidikan Olahraga, 4(2), 182-200.

Husdarta, H. J. S. (2011). Manajemen Pendidikan Jasmani (Cetakan 2). Bandung: Alfabeta.

Johnson, D. W., Johnson, R. T., \& Holubec, E. J. (2012). Collaborative Learning: Strategi Pembelajaran untuk Sukses Bersama (Cetakan 1). Bandung: Nusa Media.

Juniarti, Y. \& Gustiana, E. (2019). Pengembangan Sumber Belajar Bermain Berbasis Mobile Learning. Jurnal Pendidikan Edutama, 6(1), 37-42.

DOI: http://dx.doi.org/10.30734/jpe.v6i1.2 89

Khasanah, I., Prasetyo, A., \& Rakhmawati, E. (2011). Permainan Tradisional sebagai Media Stimulasi Aspek Perkembangan Anak Usia Dini. Jurnal Pendidikan Pudia, 1(1), 91105.

DOI: http://dx.doi.org/10.26877/paudia.v1i 1.261

Khoiriah, D. S., \& Yudiana, Y. (2016). Pengaruh Model Pembelajaran Kooperatif Tipe Team Game Tournament (TGT) terhadap Pembentukan Nilai-Nilai Kerjasama dalam Pembelajaran Permainan
Hoki. Jurnal Pendidikan Jasmani dan Olahraga, 1(1), 27-37. doi: 10.17509/jpjo.v1i1.3661

Maksum, A. (2012). Metodologi Penelitian dalam Olahraga (Cetakan 1). Surabaya: Unessa University Press.

Mckeen, K., Webb, P. I. \& Pearson, P. J. (2007). Promoting Physical Activity through Teaching Games for Understanding in Undergraduate Teacher Education. In J. A. Diniz (Eds), AIESEP 2005 World Congress (pp. 251-258). Lisboa: Faculdade de Motricidade Humana.

Nur, H. (2013). Membangun Karakter Anak melalui Permainan Anak Tradisional. Jurnal Pendidikan Karakter, 3(1), 87-94.

DOI: https://doi.org/10.21831/jpk.v0i1.129 $\underline{0}$

Palupi, W. T., \& Darmawan, G. (2017). Pengaruh Penerapan Soccer Like Games terhadap Kerjasama Siswa dalam Pendidikan Jasmani, Olaraga, dan Kesehatan (Studi Pada Peserta Didik Kelas VII di SMS Negeri 43 Surabaya). Jurnal Pendidikan Olahraga dan Kesehatan, 5(3), 510515.

Prabowo, E. M. (2015). Pengembangan Variasi dan Kombinasi Permainan Gerak Dasar Atletik Lompat dalam Pembelajaran Pendidikan Jasmani, Olahraga, dan Kesehatan untuk Siswa Kelas Pada SDN di Kecamatan Bareng Jombang. Proseding Seminar dan Workshop Keolahragaan Nasional (hal. 272293), Surabaya, 19 Septermber 2015, Universitas Negeri Surabaya, Indonesia.

Pratiwi, I. A., Ardianti, S. D., \& Kanzunnudin, M. (2018). Peningkatan Kemampuan Kerjasama melalui Model Project Based Learning (PjBL) berbantuan Metode 
Edutainment Pada Mata Pelajaran Ilmu Pengetahuan Sosial. Jurnal Refleksi Edukatika, 8(2), 177-182.

Ramadhani, S., Azwandi, Y., \& Martias. (2013). Meningkatkan Motivasi Membaca melalui Metode Bermain Peran Pada Anak Kesulitan Belajar. Jurnal Ilmiah Pendidikan Khusus, 2(3), 47-58. DOI: https://doi.org/10.24036/jupe20460.6 4

Sari, Y. (2013). Peningkatan Kerjasama di Sekolah Dasar. Bahana Manajemen Pendidikan, 1(1), 307-312. DOI: 10.23036/bmp.v1i1.2708

Suherman, A. (2009). Pengembangan Model Pembelajaran Outdoor Education Pendidikan Jasmani Berbasis Kompetensi di Sekolah Dasar. Jurnal Penelitian, 9(1), 1-16.

Suherman, A. (2010). Model Pembelajaran Pakem dalam Pendidikan Jasmani di Sekolah Dasar (Penelitian dan Pengembangan Model Pembelajaran Pakem untuk Meningkatkan Hasil Belajar Pendidikan Jasmani di Sekolah Dasar). Jurnal Penelitian Pendidikan, 11(1), 131-141.

Suherman, M. M. (2016). Efektivitas Strategi Permainan dalam Mengembangkan Self-Control Siswa. Jurnal Penelitian Pendidikan, 16(2), 194-201. Retrieved from: http://ejournal.upi.edu/index.php/JER /article/ view/4246
Suparman, S. (2010). Gaya Mengajar yang Menyenangkan Siswa (Cetakan 1). Yogyakarta: Pinus Book Publisher.

Syaukani, A. A., \& Subekti, N. (2018). Faktor Pendorong Perkembangan Positif Anak: Studi Review tentang Permainan Tradisional. Seminar Nasional Pendidikan (hal. 97-110). Surakarta, 4-5 Desember 2018, Universitas Muhamadiyah Surakarta, Indonesia.

Tomlinson, B., \& Masahura, H. (2009). Playing to Learn: A Review of Physical Games in Second Language Acquisition. Simulation \& Gaming, 20(10), 1-26.

Triyanti, E., \& Saparahayuningsih, S. (2016). Meningkatkan Kemampuan Bekerjasama melalui Permainan Simbolik. Jurnal Ilmiah Potensia, 1(1), 25-35.

Wulandari, B., Arifin, F., \& Irmawati, D. (2015). Peningkatan Kemampuan Kerjasama dalam Tim melalui Pembelajaran Berbasis Lesson Study. Jurnal Electronics, Informatics, and Vocational Education (ELINVO), l(1), 9-16. DOI: https://doi.org/10.21831/elinvo.v1i1. 12816

Wuryandani, W., Maftuh, B., Sapriya, \& Budimansyah, D. (2014). Pendidikan Karakter Disiplin di Sekolah. Cakrawala Pendidikan, 33(2), 286295.

DOI: https://doi.org/10.21831/cp.v2i2.216 $\underline{8}$ 